\title{
Clinical, epidemiological and laboratory aspects of patients with American cutaneous leishmaniasis in the State of Pernambuco
}

\author{
Aspectos clínicos, epidemiológicos e laboratoriais de pacientes \\ com leishmaniose cutânea americana \\ no Estado de Pernambuco
}

\author{
Luiza de Campos Reis ${ }^{1}$, Maria Edileuza Felinto de Brito ${ }^{1}$, Éricka Lima de Almeida ${ }^{1}$, \\ Simone Marta Félix ${ }^{1}$, Ângela Cristina Rapela Medeiros ${ }^{2}$, \\ Cláudio Júlio Silva ${ }^{3}$ and Valéria Rêgo Alves Pereira ${ }^{1}$
}

\begin{abstract}
The diagnosis for American cutaneous leishmaniasis is based on an association of clinical, epidemiological and laboratory characteristics. The present study identified the circulating species of Leishmania in the State of Pernambuco, described its clinical-epidemiological characteristics and diagnosed the disease. Nineteen patients presenting active lesions who had been diagnosed through clinical evaluation and laboratory tests were selected. The tests included direct investigation, in vitro culturing, Montenegro skin test, indirect immunofluorescence and polymerase chain reaction. The Montenegro Skin Test showed positive results in $89 \%$ of the patients; indirect immunofluorescence, in $79 \%$; direct investigation, in $58 \%$; and polymerase chain reaction in $75 \%$. Seven Leishmania (Viannia) braziliensis samples were isolated from these patients and were characterized by means of specific monoclonal antibodies. These data confirm that a combination of different diagnosis techniques is needed in order to obtain efficient results and that, so far, Leishmania (Viannia) braziliensis is the only species responsible for American cutaneous leishmaniasis infection in Pernambuco. Thus, it is essential to identify the parasite species involved in cases of human disease in an endemic area in order to determine the clinical and epidemiological characteristics, especially with regard to diagnosis, therapy development and disease prognosis.
\end{abstract}

Key-words: American cutaneous leishmaniasis. Leishmania (Viannia) braziliensis. Montenegro skin test. Indirect immunofluorescence. Polymerase chain reaction.

\section{RESUMO}

O diagnóstico da leishmaniose cutânea americana é baseado na associação dos aspectos clínicos, epidemiológicos e laboratoriais. 0 presente estudo identificou a espécie de Leishmania circulante no Estado de Pernambuco, descreveu os aspectos clínico-epidemiológicos e diagnosticou a doença. Foram selecionados 19 pacientes apresentando lesão ativa e diagnosticados através de avaliação clínica e pelos exames laboratoriais que incluíram a pesquisa direta, cultivo in vitro, intradermorreação de Montenegro, imunofluorescência indireta e reação em cadeia de polymerase. A intradermorreação de Montenegro apresentou resultado positivo em $89 \%$ dos pacientes. A imunofluorescência indireta apresentou $79 \%$ de positividade, a pesquisa direta apresentou $58 \%$ e a reação em cadeia de polymerase $75 \%$ de positividade. Sete amostras de Leishmania (Viannia) braziliensis foram isoladas desses pacientes e caracterizadas através de anticorpos monoclonais específicos. Esses dados confirmam que é necessário a combinação de diferentes técnicas diagnósticas para se obter resultados eficientes e que, até o momento, a Leishmania (Viannia) braziliensis é a única espécie responsável pela infecção da leishmaniose cutânea americana em Pernambuco. Portanto, a identificação da espécie do parasito envolvido nos casos da doença no homem em uma área endêmica é essencial para o conhecimento dos aspectos clínicos e epidemiológicos, sobretudo para o diagnóstico e para o desenvolvimento da terapia e prognóstico da doença.

Palavras-chaves: Leishmaniose cutânea americana. Leishmania (Viannia) braziliensis. Intradermoreação de Montenegro. Imunofluorescência indireta. Reação em cadeia de polymerase.

\footnotetext{
1. Centro de Pesquisas Aggeu Magalhães, Fundação Oswaldo Cruz, Recife, PE. 2. Hospital Oswaldo Cruz, Universidade de Pernambuco, Recife, PE. 3. Núcleo de Vigilância em Saúde e Ambiente, município de Moreno, PE.

This work was funded by the Molecular and Interface Nanotechnology Research Network (RENAMI), the Brazilian National Research Council (CNPq) and the Coordinating Body for Advanced Higher Education Studies (CAPES).

Address to: Dra. Valéria R.A. Pereira. Departamento de Imunologia/CPqAM/FIOCRUZ. Av. Moraes Rego s/n, Cidade Universitária, $50670-420$ Recife, PE, Brasil.

Tel: 5581 2101-2631; Fax: 5581 3453-2449

e-mail: valeria@cpqam.fiocruz.br

Recebido para publicação em 22/10/2007

Aceito em 27/08/2008
} 
American cutaneous leishmaniasis (ACL) is a vectortransmitted protozoan disease induced by different species of Leishmania. Its clinical manifestations vary from localized, disseminated skin lesions and diffuse cutaneous forms to severely mutilating mucocutaneous lesions. The clinical manifestations depend on the parasite species, the vector and the host's genetic and immunological constitution. Although some Leishmania species may generate different clinical forms, these forms are usually associated with a single species ${ }^{11}$.

The six species found in Brazil are Leishmania (Viannia) braziliensis, which is responsible for localized, disseminated and mucocutaneous forms, Leishmania (Viannia) guyanensis, Leishmania (Viannia) lainsoni, Leishmania (Viannia) shawi, Leishmania (Viannia) naiffi, which is responsible for localized cutaneous leishmaniasis, and Leishmania (Leishmania) amazonensis, which is responsible for localized cutaneous and diffuse leishmaniasis. It is essential to identify the circulating species of Leishmania in endemic areas in order to determine the disease epidemiology in the region ${ }^{14}$.

In Brazil, Leishmania (Viannia) braziliensis is highly distributed all over the national territory, and it is considered to be one of the most important species for public health. In addition to being responsible for the majority of ACL cases in this country, the forms that it is capable of inducing range from localized cutaneous lesions to severely mutilating mucocutaneous lesions $^{21}$. In the northeastern region, Pernambuco is the state with fourth greatest number of notified cases. Between 1990 and 2000, 3,268 cases were notified and, in 2004 alone, 733 cases. More than $60 \%$ of these cases occurred in the Zona da Mata ("forest

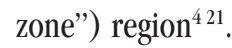

There are difficulties in diagnosing ACL because its clinical manifestations resemble ulcerated or non-ulcerated lesions from other diseases such as Virchow's hanseniasis, paracoccidioidomycosis, tropical ulcer, syphilis and cutaneous tuberculosis, among others. Moreover, there are limitations to the conventional diagnostic methods. These techniques include direct investigation, indirect immunofluorescence, ELISA (enzyme-linked immunosorbent assay), Montenegro skin test (MST), polymerase chain reaction (PCR), real-time PCR and flow cytometry. At present, there is no gold-standard test and a combination of different diagnosis techniques is often needed in order to obtain results of greater precision ${ }^{24}$.

Because of its growing distribution and its complex epidemiological characteristics, with regard not only to clinical forms, diagnosis and treatment but also to control, ACL is an endemic disease in Brazil of paramount importance for public health ${ }^{9}$. Therefore, the objectives of this study were to identify the circulating species of Leishmania in Pernambuco, describe its clinical-epidemiological characteristics and diagnose cases of ACL infection, thereby contributing towards knowledge of the epidemiological aspects of this disease in northeastern Brazil, a region where the incidence of this disease has been increasing considerably.

\section{MATERIAL AND METHODS}

Patients. During the year 2005, nineteen patients of both genders were selected from the municipalities of Moreno, Camaragibe, Amaraji and Vitória de Santo Antão. These municipalities are located in the Zona da Mata region, which is an endemic area for ACL in Pernambuco, in northeastern Brazil. The criterion for patient selection was based on the presence of active lesions and confirmed diagnosis. The patients were treated at the Aggeu Magalhães Research Center (CPqAM/FIOCRUZ), under medical supervision, where the diagnostic evaluations were also performed. The material collected was processed in the Immunoparasitology Laboratory of the Immunology Department of CPqAM/FIOCRUZ. The experimental protocols had previously been approved by the Ethics Committee of CPqAM/FIOCRUZ (no. 27/04).

Direct investigation and parasite isolation. Direct investigation was performed on material obtained from scratches on the lesion margins, using a sterile surgical blade. Smears were placed on glass slides, fixed with methanol and bleached using Giemsa, to identify amastigotes by means of optical microscopy. Aspirated punctures were performed using disposable syringes containing $0.3 \mathrm{ml}$ of sterile saline solution, applied to the lesion border. The aspirated content was then inoculated in hamsters (Mesocricetus auratus) intraperitoneally. After three months, these animals were sacrificed in order to obtain their spleens, with the aim of attempting to isolate the parasite in Nicolle, New and $\mathrm{McNeal}(\mathrm{NNN})$ and Schneider medium. From the biopsy, which was performed using a punch measuring 4-6mm in diameter, one part of the fragments removed from the border of the active lesion was used for the attempt to isolate the parasite in NNN/Schneider medium. The other part was used for diagnosing the parasite DNA by means of PCR. Cultures were examined every five days in order to confirm whether isolation had occurred. Characterization of the Leishmania species by means of in vitro parasite isolation was accomplished using the monoclonal antibody technique, with a panel of 23 monoclonal antibodies (B2, B5, B11, B12, B13, B18, B19, C01, C02, C03, D13, L1, LA2, M2, N2, N3, V1, WA2, W1, W2, WH1, WIC and T3). This was carried out in collaboration with the Evandro Chagas Institute, in Belém² ${ }^{22}$

Polymerase chain reaction. The Genomic Prep Cell and Tissue DNA Isolation Kit (Amersham Biosciences) was used for PCR, in accordance with the manufacturer's protocol for DNA extraction from biopsies. The DNA obtained was subjected to amplification in an automatic thermocycler (Px2 Model, Thermo Electron Corporation), using the primers 5'-GGGGTTGGTGTAATATAGTGG-

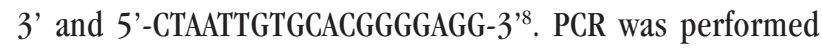
in a final volume of $25 \mu \mathrm{l}$ containing $10 \mathrm{mM}$ Tris- $\mathrm{HCl}, 50 \mathrm{mM}$ $\mathrm{KCl}, 0.1 \mathrm{mg} / \mathrm{ml}$ gelatin, $1.5 \mathrm{mM} \mathrm{MgCl}_{2}, 0.2 \mathrm{mM}$ deoxynucleoside triphosphate, $25 \mathrm{pmol}$ of each of the primers, 2.5U of Taq DNA polymerase (Amersham Pharmacia Biotech) and $2 \mu \mathrm{l}$ of sample. The amplification consisted of 35 cycles: $94^{\circ} \mathrm{C}(1 \mathrm{~min}), 65^{\circ} \mathrm{C}$ (1 min) and $72^{\circ} \mathrm{C}(1 \mathrm{~min})$, preceded by an initial denaturation of 5 minutes at $94^{\circ} \mathrm{C}$. PCR products $(10 \mu \mathrm{l})$ were analyzed by means of electrophoresis on 1\% agar gel with TAE buffer (Tris-acetate 40mM, EDTA 1mM), which was bleached with ethidium bromide in order to view the 750bp target (corresponding to the Viannia species) in a UV transilluminator ${ }^{19}$. 
Montenegro skin test and indirect immunofluorescence reaction. The Montenegro skin test was performed via intradermic inoculation of $0.1 \mathrm{ml}$ of the antigen (leishmanin) produced by Biomanguinhos/FIOCRUZ, into the anterior face of the forearm. The skin tests were read after 48 or 72 hours, and induration greater than or equal to $5 \mathrm{~mm}$ was considered positive. Indirect immunofluorescence was performed using the human IIF-Leishmaniasis kit produced by Biomanguinhos/FIOCRUZ, in accordance with the manufacturer's instructions. Parasite fluorescence in 1:40 dilution was taken to be positive.

\section{RESULTS}

In this study, there were 13 male patients (68\%) and 6 female patients (32\%), aged 13 to 75 years, with a mean age of 36 years. Only one patient presented the disseminated cutaneous form, with over 20 papular lesions spread all over the body surface. One other patient also presented a mucocutaneous form. All the other patients presented well-characterized ulcerated lesions, with elevated borders and granulomatous bases, distributed on uncovered areas of the body. In relation to the number of lesions, $68 \%$ of the patients showed only one lesion; $16 \%$, two lesions; $11 \%$, three lesions; and $5 \%$, more than three lesions. All the patients showed complete healing of the lesions by the end of the course of therapy with Glucantime ${ }^{\circledR}$. The patients were followed up for a period of 12 months after the end of the treatment to confirm that clinical cure had been achieved and to monitor for the appearance of any new lesions and recurrences. Most (95\%) of the patients presented a clinical cure with complete healing. The therapeutic scheme for the majority (63\%) of the patients consisted of only one series (20 to 30 days). In $26 \%$ and $11 \%$ of the patients, the treatment consisted of two and three series, respectively. As shown in Table 1, all the patients showed a positive diagnosis for ACL in at

\begin{tabular}{|c|c|c|c|c|c|}
\hline Patients & $\begin{array}{c}\text { MST } \\
(\mathrm{mm})\end{array}$ & $\begin{array}{c}\text { Direct } \\
\text { investigation }\end{array}$ & IIF & PCR & $\begin{array}{l}\text { Parasite } \\
\text { isolation }\end{array}$ \\
\hline 1 & 10 & + & - & - & - \\
\hline 2 & 5 & + & - & - & - \\
\hline 3 & 10 & + & - & + & + \\
\hline 4 & 20 & + & + & + & - \\
\hline 5 & 15 & + & + & + & - \\
\hline 6 & 20 & + & - & - & - \\
\hline 7 & 15 & + & + & + & - \\
\hline 8 & NR & - & + & + & - \\
\hline 9 & 10 & - & - & + & + \\
\hline 10 & 5 & + & + & + & - \\
\hline 11 & 20 & + & + & + & + \\
\hline 12 & 10 & - & + & + & - \\
\hline 13 & 10 & + & + & - & + \\
\hline 14 & - & + & + & + & + \\
\hline 15 & 15 & - & - & + & - \\
\hline 16 & 15 & - & + & + & + \\
\hline 17 & 20 & - & + & $\mathrm{NP}$ & + \\
\hline 18 & 5 & - & + & $\mathrm{NP}$ & - \\
\hline 19 & 6 & - & + & $\mathrm{NP}$ & - \\
\hline
\end{tabular}

MST: Montenegro skin test, IIF: indirect immunofluorescence, PCR: polymerase chain reaction, +: positive, -: negative, NP: not performed. least one of the tests performed. There was a positive result from the Montenegro skin test, i.e. induration greater than or equal to $5 \mathrm{~mm}$, in $89 \%$ of the patients, with induration sizes ranging from 5 to $20 \mathrm{~mm}$. This test showed a strong skin sensitivity response, that is, indurations higher than $10 \mathrm{~mm}$ in the great majority ( $72 \%)$ of the patients. There were positive results from indirect immunofluorescence in $79 \%$ and from direct investigation in $58 \%$. In seven (37\%) individuals, the parasite was isolated in the culture medium and, after analysis using monoclonal antibodies, it was classified as Leishmania (Viannia) braziliensis. PCR was performed on 16 out of the 19 patients, and $75 \%$ of the results were positive (Figure 1).

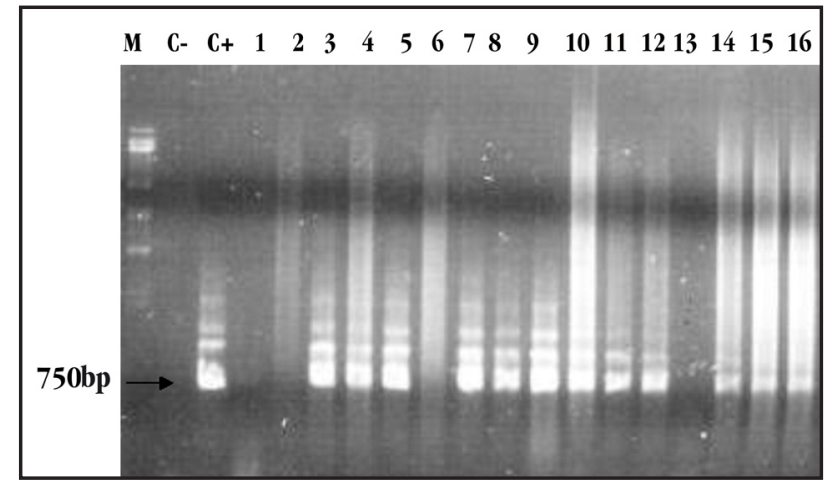

Figure 1 - Polymerase chain reaction amplification of Leishmania in biopsy samples (lanes 1-16) obtained from patients with American cutaneous leishmaniasis. M: (size marker $\lambda+$ Hind III), C: negative control, C: positive control.

\section{DISCUSSION}

This study assessed the clinical, epidemiological and laboratory characteristics of patients with American cutaneous leishmaniasis and identified the species responsible for causing the infection in the State of Pernambuco.

Most of the clinical forms observed in this study were the localized cutaneous form, with ulcerated lesions on uncovered areas of the body (89\%). The existence of lesions on uncovered areas of the body, usually on the upper and lower limbs, may be explained by the occupational activities performed by the patients. The great occurrence of the localized cutaneous form of ACL in our study is in accordance with other studies in Pernambuco and with studies in other states to $0^{4620}$. On the other hand, the trend towards reduced numbers of occurrences of mucocutaneous leishmaniasis is probably due to better knowledge of the disease, thereby leading to early treatment and accurate diagnosis ${ }^{13}$. Mucous manifestations may appear while cutaneous lesions are still active, or years after the healing, and are usually associated with delayed healing of the primary lesion and inadequate treatment ${ }^{12}$.

Chemotherapy treatment is primarily based on administration of pentavalent antimonials; Glucantime ${ }^{\circledR}$ is the one used in Brazil. These antimonials are highly toxic and are administered intramuscularly for prolonged periods. Despite the large number of side effects described in the literature, the patients in the present study did not report any adverse reactions to the treatment. Another reason for difficulty in treating ACL and for the tendency 
for treatment to be interrupted is that the disease occurs in distant rural areas where access to health services is difficult. Moreover, there is often a need for exclusively parenteral therapies ${ }^{20}$.

In addition to toxicity, another limitation to the treatment is the absence of objective cure criteria. The cure criterion adopted by many authors has been complete healing of the lesion. Nevertheless, this is an unsatisfactory criterion, since reactivation of the lesions may occur even after the treatment. Even though the cutaneous lesions caused by Leishmania (Viannia) braziliensis are usually susceptible to antimony treatment, and healing occurs by the end of the therapy, the ACL recurrence rate is more than 90\% within the first year after treatment. This strengthens the suggestion that there should be clinical control for at least one year post-treatment ${ }^{7}$. Furthermore, an efficient cell-mediated immune response is necessary for maximum efficacy of the treatment with pentavalent antimonials, since parasite-induced immunosuppression occurs ${ }^{3}$. Together with these characteristics, the existence of several parasite species and vectors and several parasite-host relationships contributes towards the complexity of ACL. This leads to the need for new tools that might help to determine the diagnosis and prognosis efficiently.

American cutaneous leishmaniasis diagnosis is achieved through an association of clinical, epidemiological and laboratory characteristics. In the present study, the diagnosis was confirmed by means of direct investigation, parasite isolation in culture medium, Montenegro skin test, indirect immunofluorescence and polymerase chain reaction. The patients showed positive results in at least one of the diagnostic tests. For operational reasons, some patients could not be diagnosed by all the methods used.

The results achieved in the Montenegro skin test among our patients were in accordance with the findings of other authors, who reported sensitivity of around 90\% in ACL cases ${ }^{10}{ }^{13}$. Only one patient showed a negative response. The result in that case may be explained by the fact that it was a recent infection and the patient had not lived in an endemic area previously. It is also common for the Montenegro skin test to show positive results among individuals from endemic areas, because of the occurrence of subclinical infections. Moreover, the Montenegro skin test does not distinguish between past or recent infection ${ }^{24}$.

Serological tests like indirect immunofluorescence, which showed a high sensitivity in the present study, may present limitations such as an absence of correlation between circulating antibody levels and disease stage. They can also show crossreactions with other species of the Trypanosomatidae family. Because of the limitations of such techniques, immunological approaches have been used. One of them is flow cytometry, which allows detection of antiLeishmania antibodies ${ }^{18}$.

Another methodology used is the polymerase chain reaction. This offers the best sensitivity and specificity rates and is able to detect low quantities of parasites in the infection. Other authors have also found results like ours. Nevertheless, it is unviable to apply PCR in population studies because of its high $\operatorname{cost}^{1625}$

Parasite isolates obtained from in vitro culturing of promastigotes were analyzed by means of monoclonal antibodies and were identified as Leishmania (Viannia) braziliensis. The seven isolate samples obtained are of great significance because of the difficulties in culturing of this Leishmania species. Previous studies in Pernambuco have also identified this species through monoclonal antibodies and isoenzyme techniques ${ }^{15}$. This finding confirms that the only circulating species of Leishmania so far found to be responsible for ACL infection in Pernambuco is Leishmania (Viannia) braziliensis.

It is important to highlight that one characteristic of all Leishmania species is the tendency for there to be non-manifested infection or parasite persistence after the lesion has healed ${ }^{17}$. Demonstration of such persistence, in material obtained from the scars of individuals who have achieved clinical cure, raises several issues concerning the clinical evolution and epidemiology of leishmaniasis and the strategies for controlling $\mathrm{it}^{15}$.

Armijos et $\mathrm{al}^{2}$ recommended that the search for alternative therapies and immunoprophylactics should be prioritized among the strategies for controlling this disease. Moreover, it is essential to identify the parasite species involved in cases of human disease in endemic areas, in order to understand the clinical and epidemiological characteristics that are indispensable with regard to diagnosis, therapy development and disease prognosis. Thus, the results from the present study strengthen the view that, in addition to the need to identify the species responsible for the disease, early diagnosis of ACL cases is required.

\section{ACKNOWLEDGEMENTS}

We are grateful to Mineo Nakazawa, Wlademir Melo and Simone Reis for technical assistance. We also thank Dr Edna Ishikawa from the Evandro Chagas Institute, Fundação Oswaldo Cruz, for characterization of Leishmania species using the monoclonal antibody technique. Luiza de Campos Reis received a CAPES MSc scholarship for the duration of this research project.

\section{REFERENCES}

1. Andrade MS, Brito MEF, Silva ST, Lima BS, Almeida EL, Albuquerque EL, Marinho Junior JF, Ishikawa E, Cupolillo E, Brandão Filho SP. Leishmaniose tegumentar americana causada por Leishmania (Viannia) braziliensis, em área de treinamento militar na Zona da Mata de Pernambuco. Revista da Sociedade Brasileira de Medicina Tropical 38: 229-233, 2005.

2. Armijos RX, Weigel MM, Calvopina M, Mancheno M, Rodriguez R. Comparison of the effectiveness of two topical paromomycin treatments versus meglumine antimoniate for New World cutaneous leishmaniasis. Acta Tropica 91:153-160, 2004.

3. Berger BJ, Fairlamb AH. Interactions between immunity and chemotherapy in the treatment of the trypanosomiases and leishmaniasis. Parasitology 105:S71-S78, 1992.

4. Brandão-Filho SP, Campbell-Lendrum D, Brito ME, Shaw JJ, Davies CR. Epidemiological surveys confirm an increasing burden of cutaneous leishmaniasis in north-east Brazil. Transactions of the Royal Society of Tropical Medicine and Hygiene 93:488-494, 1999.

5. Brito ME, Brandao SP, Salles NR, Cupolillo E, Grimaldi Junior G, Momen H. Human cutaneous leishmaniasis due to a new enzymatic variant of Leishmania (Viannia) braziliensis occurring in Pernambuco, Brazil. Memórias do Instituto Oswaldo Cruz 88:633-634, 1993. 
6. Costa JML, Balby ITA, Rocha EJS, Silva AR, Rebelo JMM, Ferreira LA, Gama MEA, Branco MRFC, Burattini MN, Soares NJS. Comparative study of american tegumentary leishmaniasis between childhood and teenagers from the endemics areas Buriticupu (Maranhão) and Corte de Pedra (Bahia), Brasil. Revista da Sociedade Brasileira de Medicina Tropical 31:279-288, 1998.

7. Coutinho SG, Oliveira MP, Da-Cruz AM, De Luca PM, Mendonça SC, Bertho AL, Soong L, McMahon-Pratt D. T-cell responsiveness of American cutaneous leishmaniasis patients to purified Leishmania pifano $i$ amastigote antigens and Leishmania braziliensis promastigote antigens: immunologic patterns associated with cure. Experimental Parasitology 84:144-155, 1996.

8. De Bruijn MHL, Barker DC. Diagnosis of New World leishmaniasis: specific detection of species of the Leishmania braziliensis complex by amplification of kinetoplastid DNA. Acta Tropica 52:45-58, 1992.

9. Dorval ME, Oshiro ET, Cupollilo E, Castro AC, Alves TP. Occurrence of American tegumentary leishmaniasis in the Mato Grosso do Sul State associated to the infection for Leishmania (Leishmania) amazonensis. Revista da Sociedade Brasileira de Medicina Tropical 39:43-46, 2006.

10. Faber WR, Oskam L, van Gool T, Kroon NC, Knegt-Junk KJ, Hofwegen H, van der Wal AC, Kager PA. Value of diagnostic techniques for cutaneous leishmaniasis. Journal of the American Academy of Dermatology 49:70-74, 2003.

11. Garcia AL, Kindt A, Quispe-Tintaya KW, Bermudez H, Llanos A, Arevalo J, Bañuls AL, De Doncker S, Le Ray D, Dujardin JC. American tegumentary leishmaniasis: antigen-gene polymorphism, taxonomy and clinical pleomorphism. Infection, Genetics and Evolution 5:109-116, 2005.

12. Gontijo B, Carvalho MLR. Leishmanose Tegumentar Americana. Revista da Sociedade Brasileira de Medicina Tropical 36:71-80, 2003.

13. Gontijo CMF, Silva ES, Fuccio MB, Souza MCA, Pacheco RS, Dias ES, Andrade Filho JD, Brazil RP, Melo MN. Epidemiological studies of an outbreak of cutaneous leishmaniasis in the Rio Jequitinhonha Valley, Minas Gerais, Brazil. Acta Tropica 81:143-150, 2002

14. Gramiccia M, Gradoni L. The current status of zoonotic leishmaniases and approaches to disease control. International Journal of Parasitology 35:1169-1180, 2005.

15. Mendonça MG, Brito ME, Rodrigues EH, Bandeira V, Jardim ML, Abath FG. Persistence of Leishmania parasites in scars after clinical cure of American cutaneous leishmaniasis: is there a sterile cure? The Journal of Infectious Diseases 189:1018-1023, 2004

16. Pirmez C, Silva Trajano VS, Paes-Oliveira Neto M, da-Cruz AM, Gonçalves-daCosta SC, Catanho M, Degrave W, Fernandes 0. Use of PCR in diagnosis of human American tegumentary leishmaniasis in Rio de Janeiro, Brazil. Journal Clinical of Microbiology 37:1819-1823, 1999.

17. Ramírez JL, Guevara P. Persistent infections by Leishmania (Viannia) braziliensis. Memórias do Instituto Oswaldo Cruz 92:333-338, 1997.

18. Rocha RD, Gontijo CM, Eloi-Santos SM, Carvalho AT, Correa-Oliveira R, Marques MJ, Genaro 0, Mayrink W, Martins-Filho OA. Anti-live Leishmania (Viannia) braziliensis promastigote antibodies, detected by flow cytometry, to identify active infection in american cutaneous leishmaniasis. Revista da Sociedade Brasileira de Medicina Tropical 35:551-562, 2002.

19. Rodrigues EHG, Brito MEF, Mendonça MG, Werkhäuser RP, Coutinho EM, Souza WV, Albuquerque MFPM, Jardim ML, Abath FGC. Evaluation of PCR for Diagnosis of American Cutaneous Leishmaniasis in an Area of Endemicity in Northeastern Brazil. Journal of Clinical Microbiology 40: 3572-3576, 2002.

20. Rodríguez AM, Hueb M, Santos TA, Fontes CJ. Factors associated with treatment failure of cutaneous leishmaniasis with meglumine antimoniate. Revista da Sociedade Brasileira de Medicina Tropical 39:139-45, 2006.

21. Secretaria de Vigilância em Saúde de Pernambuco. Relatório de Situação: Pernambuco. Ministério da Saúde, Brasília, $2^{\text {a }}$ edição, 2006.

22. Shaw JJ, Ishikawa EA, Lainson R. A rapid and sensitive method for the identification of Leishmania with monoclonal antibodies using fluoresceinlabeled avidin. Transactions of the Royal Society of Tropical Medicine and Hygiene 83: 783-784, 1989.

23. Silveira FT, Lainson R, Corbett CE. Clinical and immunopathological spectrum of American cutaneous leishmaniasis with special reference to the disease in Amazonian Brazil: a review. Memórias do Instituto Oswaldo Cruz 99:239-251, 2004.

24. Vega-López F. Diagnosis of cutaneous leishmaniasis. Current Opinion in Infectious Diseases 16:97-101, 2003.

25. Weigle KA, Labrada LA, Lozano C, Santrich C, Barker DC. PCR-based diagnosis of acute and chronic cutaneous leishmaniasis Caused by Leishmania (Viannia). Journal of Clinical Microbiology 40:601-606, 2002. 